to observe the behaviour of Wilbert Cream, the notorious New York playboy, who is thought to have stolen the celebrated cow-creamer.

Sir Roderick, even when clothed with the magic mantle of butlerdom, is quite unable to unravel the amazing imbroglio which ensues at Brinkley. Fortunately, Jeeves returns to the scene, refreshed after his shrimping holiday at Herne Bay, rapidly resolving everybody's problem and placating the Creams by suggesting to them that Sir Roderick was masquerading as a butler in order to observe Bertie Wooster's behaviour.

Although nearly all the recorded evidence about Sir Roderick's career is concerned with his relationship with Bertram Wooster, fortunately, the archive contains this revealing exchange: "I wish I had a brain like yours,' said Lord Ickenham, 'What an amazing thing; I suppose you can walk down a line of people, giving each of them a quick glance, and separate the sheep from the goats like shelling peas ... "loony ... not loony ... this one wants watching ....this one's all right . . . keep an eye on this chap, don't let him get near the breadknife." Extraordinary! What do you do, exactly? Start topics and observe reactions?'

" 'Yes. I suppose you might say-broadly-that that is the method I employ'."

On such a foundation was not only a giant individual reputation laid but also the mighty edifice of modern psychiatric practice.

\title{
"O that I were young again": Yeats and the Steinach operation
}

\author{
STEPHEN LOCK
}

How can I, that girl standing there, My attention fix

On Roman or on Russian

Or on Spanish politics?...

And maybe what they say is true

Of war and war's alarms

But $O$ that I were young again

And held her in my arms!

In late middle age W B Yeats passed through a phase of gloom and inactivity. Suddenly he took on a new lease of life, embarking on fresh activities and producing the superb poems of his last years. The cause of this change, I would suggest, whether physical or psychological, was a "rejuvenation" operation-the Steinach procedure which Yeats underwent in the spring of 1934.

Without the effects of this operation we may ask certain questions. Would Yeats have become such close friends with Margot Ruddock, a young poet, actress, and dancer, who came on to the scene some six months after the operation? To make a more tentative suggestion, a year later would he have taken on such vigorous new friendships, as with Lady Dorothy Wellesley and Ethel Mannin, or fresh projects, such as the BBC readings of his poetry accompanied by a fiddle or a drum ? Would he, also a year after the operation, have had the audacity to make such a bizarre selection of poems for the Oxford Book of Modern Verse -which excluded some of the poets of the first world war, such as Wilfred Owen, as well as some of the best work of the new school of Auden, Day-Lewis, and Spender-not to mention also leaving out distinguished contemporary Irish poets, such as Austin Clarke. ${ }^{1}$ And, finally, would we have had those marvellous poems of the last few years-when he said "lust and rage" were dancing attendance on him ?

We shall never know the definitive answers to any of these questions, but it is worth examining the circumstances. The idea of surgical operations aimed at restoring sexual potency or at rejuvenation goes back at least to Claude Bernard. He established that glands could be classified into the exocrine and the

British Medical Journal London WC1H 9JR

STEPHEN LOCK, MB, FRCP, editor

Based on a talk given on 6 May 1983 at Thor Ballylee, Yeats's country house, to the section of the history of medicine of the Royal Academy of Medicine in Ireland. endocrine varieties, ${ }^{2}$ and it was his successor in the chair at Paris, Charles Brown-Séquard, who put theory into practice. By giving himself regular injections of an aqueous extract of guinea pig testes, Brown-Séquard claimed that at the age of 72 he felt 30 years younger. In the famous lecture in which he announced this Brown-Séquard said that that morning he had paid a visit to Mme Brown-Séquard, the phrase in French, "faire une visite," having a double entendre. ${ }^{3}$

The public reacted to Brown-Séquard's claims with enthusiasm-there was little doubt that such injections did have some effects but they proved to be transitory; and, after a few years, the work was largely forgotten. Even so, at about the same time that Brown-Séquard was making his initial claims in Paris, a young Austrian physiologist was starting research into the physiology of animal gonads.

This physiologist was Eugen Steinach, born in 1861, who had worked in both Innsbruck and Prague before he was appointed professor of physiology at the University of Vienna in 1912.4 Working with rats, Steinach came to three conclusions. Firstly, that the testis contained both exocrine and endocrine elements; secondly, that castration diminished the sex characteristics and that these reappeared once the testes were implanted again; and, thirdly, that old rats who were given a testicular implant from young rats underwent rejuvenation: they showed a general improvement but particularly an "insatiable" interest in sexual activity.

\section{Steinach operation}

Finally, Steinach found that it was the endocrine cells of the graft which survived, and hypertrophied, and that the same effect could be produced without a transplant by increasing the blood flow to the animal's own testis. This could be done by ligating the vas deferens, and, to see whether there would be any effect in human subjects, Steinach asked a Viennese surgeon, Karl Lichtenstern, to try the operation out.

The first operation for rejuvenation was carried out in 1918 and its effects are well described in Steinach's own book. ${ }^{5}$

"The patient was a man who was not aged in years but who was particularly suitable as an object lesson in the effects of vasoligature because his general condition presented a typical picture of premature senility without organic disease. $\mathrm{He}$ was a perfect example of presenile exhaustion. 
"Anton W, coachman, was 43 years of age on his admission to hospital. For some time he had observed rapid exhaustion after work and greatly lessened working capacity; he had been feeling miserable during the last few weeks, suffered difficulty in breathing, loss of appetite, and loss of weight.

"The patient presented the appearance of an exhausted and prematurely old man; his weight was 108 pounds, his musculature was weak, and there was very little cushion of fat. . . .

"Postoperative healing was perfectly normal. Nevertheless, the patient was kept in the hospital eight weeks because he was the first case (subsequent cases mostly left the hospital after two to three days). Continued observation showed that during these two months there had been no particular signs of a rapid recovery. He was discharged from the hospital, resumed his work as a coachman, and in spite of hard work was unable to provide himself with proper nourishment. He rarely could afford fat or meat. His diet consisted mainly of inferior bread and vegetables, owing to the shocking conditions of living which prevailed generally in Vienna at that time as a consequence of the Great War.

"Notwithstanding this inadequate nutrition, the man recovered rapidly, beginning the third month after the operation. One year later he was in splendid physical condition; his weight had increased by 35 pounds. 'The ex-patient now drags loads up to 220 pounds with ease. His muscles have developed extraordinarily. The hair on his head is thicker and his beard more strongly developed. The head and face hair grow so quickly that he has to have it cut and shaved twice as often as previously; the same rapid growth is noticeable in the nails of his fingers and his toes. The skin appears soft, with fine down, pliable and moist. Pulse 82 , normal; blood pressure 130.'

"This record concludes with the words: 'Now, about eighteen months after the vasoligature, this man with his smooth, unwrinkled face, his smart and upright bearing, gives the impression of a youthful man at the height of his vitality."

By the 1930s thousands of procedures had been carried out all over the world, usually on one side and under local anaesthesia. Enormous anecdotal claims were made for this "Steinach operation." It was said that men appeared years younger; that their sexual interests revived; and that they often took a new interest in their profession or their business. Books were published on the subject and it seems likely that a number of prominent people had the operation done, even if orthodox medical opinion probably poohpoohed the idea-and certainly there seem to be few serious scientific reports in the medical journals.

In $1934 \mathrm{~W}$ B Yeats was aged 69. His companion and spiritual mentor Lady Gregory had been dead for two years-and her great house Coole Park, which had meant so much to the poet, had been sold to the Forestry Commission and was empty. Although he had expected Lady Gregory to die, Yeats told Mario Ross at the time that he had lost one who had "been to me for nearly 40 years my strength and my conscience." 6 After Lady Gregory's death in May 1932 he wrote no poetry for virtually a year, though in the autumn of that year he did embark on a prolonged tour of the United States to raise funds for the Irish Academy of Letters. It was to be his last trip to the USA. Early in 1934, Joseph Hone tells us in his biography, "Yeats called on a friend; he was dejected and out of sorts, saying that he had no wish to live a long time unless he could continually recreate himself. To cheer him up, his friend recounted the recently published description of the Steinach operation, whereupon Yeats rushed off to Trinity College library to consult the book, which had just appeared. According to Joseph Hone, again, Yeats's doctor in Dublin would not give him an opinion either way, so that the poet took himself off to London, where he underwent the operation. Striding into his friend's office some two months later, looking like another man, he said "I had it done."

\section{Who did the operation?}

I have heard a different version of the story of how Yeats came to hear about the operation. The poet and biographer Jon Stallworthy-who has written two superb books about Yeats's poetry in the making ${ }^{89}$ and was a great friend of the late Sir Geoffrey Keynes-says that he believed that Sir Geoffrey had carried out a Steinach procedure on Sturge Moore (Stallworthy, personal communication 1982). Sturge Moore, one of the foremost illustrators of his day, had done several designs for the covers of books of Yeats's poems, most notably The Tower, so it would not be surprising if Yeats had learnt about the operation from Moore himself. Sir Geoffrey Keynes told me that he had met Yeats only on one social occasion, but alas he died before I was due to meet him and ask him all about the Steinach operation. In any case, as one might expect, Yeats's friend Oliver St John Gogarty, ENT surgeon, wit, and poet, has his own comment about it: "Yeats's disdain for science," he says, "led him into what was a singular experiment. It left him open to the highly coloured claims of rejuvenating operations. I was horrified to hear when it was too late that he had undergone such an operation."10 According to another account, one of Gogarty's objections was based on the belief that Yeats had haemophilia, and so might bleed excessively after the operation. ${ }^{11}$ Gogarty had earlier taken out Yeats's tonsils so perhaps the haemorrhage after this operation had given him this, otherwise unsupported, belief.

The man who carried out the operation on Yeats was most probably Norman Haire, an Australian sexologist who practised in Harley Street. Haire was as much concerned with the contraceptive movement of Marie Stopes as with the Steinach procedure, though he did publish a popular work on Rejuvenation in $1934,{ }^{12}$ the year that Yeats had his operation. In his book Haire comes to several conclusions based on a study of his own 25 cases as well as those of several other surgeons. ${ }^{8}$

Firstly, he says, the operation of vasoligature and vasectomy has no ill effects. No doubt people had occasionally died some time after the operation, as in the case of Albert Wilson, ${ }^{*}$ but the evidence led him to believe that the death could not be attributed to the operation itself. Secondly, the operation is not universally successful. It cannot be expected to cure all the ills that flesh is heir to-to cure cancer or restore an irreparably damaged organ to its original healthy condition. Nevertheless, even in cases of organic disease or advanced senility the operation often ameliorates the condition to some extent. Thus, fourthly, it is most clearly indicated where there is no organic disease and where senility has not proceeded too far. In successful cases, for example, it may lower high blood pressure ; increase muscular energy; stimulate appetite for food; relieve insomnia and indigestion; cause improved nutrition of skin and renewed growth of hair; improve power of concentration, memory, temper, capacity for mental work; and possibly increase sexual desire, potency, and pleasure. Not all these changes appear in every case, nor does this list cover all the changes that may appear.

The evidence for my belief that Haire was the surgeon comes from a brief mention in a letter to Ethel Mannin of Yeats having had a check up from Haire. ${ }^{13} \mathrm{Mr}$ John Kelly, who is editing all Yeats's letters for publication, believes that Haire introduced Yeats to Mannin, but tells me that Haire's executor burnt all his papers because these contained correspondence from a number of distinguished persons which might have caused embarrassment if they had fallen into the wrong hands (Kelly, personal communication 1982).

Even so, unless there are letters or other documents that have not yet emerged that is most of what we can gather about Yeats and the Steinach operation. And yet we can piece together a number of other bits of the jigsaw. We know, for instance, that Yeats's health had broken down seven years before the operation;

* Albert Wilson was one of Steinach's patients who died the day before he was to have delivered a lecture on "How I was made Twenty Years Younger" at the Albert Hall. This did not surprise those who really knew anything about his case. Norman Haire comments: "He was a man over seventy, who had been most successfully operated on by Steinach some time before; but too confident in his renewed vigour, he overtaxed his powers and died from an attack of angina pectoris, a disease from which he had suffered for many years before the operation. He had been warned not to be prodigal of his newfound strength, but forgot that he was in his seventies and tried to live like a young man in the twenties. The result, of course, was disaster." 
he had had congestion of the lungs, his blood pressure had been found to be raised, and he had taken a prolonged convalescence in Spain, Cannes, and Rapallo. ' Again, in 1929, he had been found to be suffering from brucellosis and he had convalesced in Portofino and Rapallo from March until July. The following year he had had a check up from his doctor, who had told him that he was a "wonderful" man but that his blood pressure was up.

For the next five years we hear little about his health, but there are a few significant passages in the letters. Writing to Olivia Shakespear in August 1933, ${ }^{14}$ he talks about the love poems in his new book The Winding Stair. "Sexual abstinence fed their fire-" he says, "I was ill and yet full of desire." In March 1934, presumably a month or so before the Steinach operation, Yeats (in an unpublished letter ${ }^{15}$ ) declines an invitation to the Morris Centenary Celebrations, saying that the journey is more than he has time or strength for. And yet in May he is writing to Olivia Shakespear again: "It is too soon to know whether I have benefited by the operation but I feel as if my blood pressure was down-I am not irritable and that is a new event." 16 On 1 June he writes ${ }^{17}$ : "I am still marvellously strong, with the sense of a future ...." and over a year later, on June 24 , 1935, he concludes a letter to Ethel Mannin by saying "I feel very well, full of energy and life but I am soon made breathless if I am not careful. . . . I was worse before the operation." 8 Finally, commenting on Hone's biography of Yeats, ${ }^{7} \mathrm{~L} \mathrm{~A} \mathrm{G}$ Strong describes a conversation with the poet about the operation $^{1 \times: 1}$ :

"The Steinach operation receives little mention. Did it play some part in the ribaldry of The Herme's Eggs and the preoccunations of some of the last poems ? Or did Yeats choose it because of those preoccupations? That he knew it was important, and guessed what it might cost on the psychic level, I knew from a conversation I had in London not long after he underwent it. AE's name came into the conversation, and Yeats said, 'He is physically enfeebled. He should have the operation,' and added, with a flash through his strong lenses, 'He would die sooner.'"'

\section{Margot Ruddock}

It was in the autumn of 1934, six months after he had had his Steinach operation, that Yeats met Margot Ruddock, a young and attractive poet and actress. Comparatively little about their relationship appears in Yeats's letters or most published books about him, yet evidently there was some gossip and tittle tattle in the daily papers, and Dublin, which always delights in mocking its great figures, began to call him "the gland old man." Eventually all this died down and later generations had to wait until 1970, when Professor Roger McHugh published his account of the events in a book entitled $A h$, Sweet Dancer." "In 1964 McHugh learnt that some letters still existed of exchanges between the poet and Margot Ruddock, whose daughter then allowed him to take photostat copies. Mrs Yeats was anxious that these letters should not be published during the Yeats's centenary year, but agreed that they should appear eventually and should not be censored; she gave Professor McHugh such copies as there were of Margot Ruddock's letters, poems, and other documents. In total, the final book contains 31 letters by Yeats, 36 letters by Margot Ruddock, some poems by both (one by Yeats printed for the first time), and an account by Margot Ruddock of a psychotic episode.

Margot Ruddock and Yeats first met on 4 October, 1934; in a letter written to her next day she was "My dear Margot" and "Yours always," although he was usually a formal man. Yeats saw her as "a woman of distinguished beauty of face and limb" - a fact which is confirmed by her photographs and by Sir Frederick Ashton, who, remembering that Yeats was very taken with her, found her very intense and seemingly a lost soul." $\mathrm{A}$ week after their first meeting Yeats was rewriting The King of the Great Clock Tower (the play that eventually became $A$ Full Moon in March) to give the Queen a speaking part that Margot would act. The play, Yeats says, will now open with a song partly addressed to Margot Ruddock; and the second stanza contains a moving and wistful passage:

Should old Pythagoras fall in love

Little may he boast thereof

(What cares love for this and that?)

Days go by in foolishness

But $\mathrm{O}$ how great the sweetness is.

The letters, which are very affectionate on her part, speak not only of their mutual attraction but also discuss the technique of writing and speaking poetry, the scandals in the theatre on both sides of the Irish Sea (for primarily Margot Ruddock and her

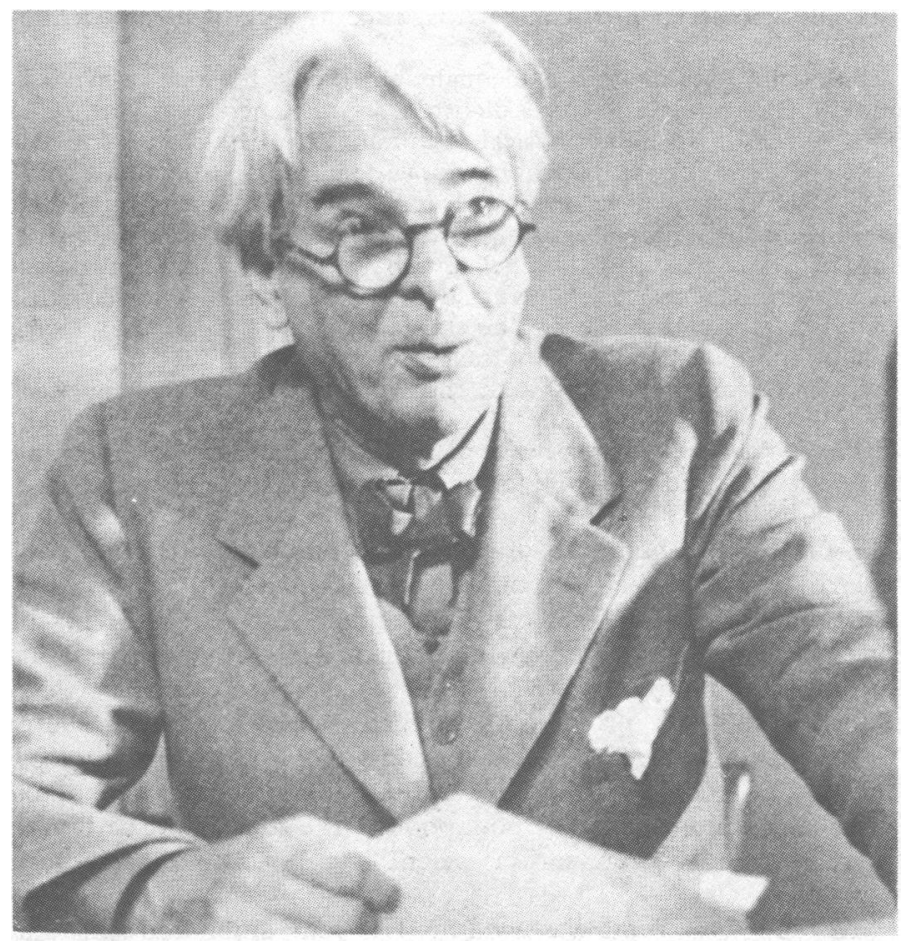

W B Yeats, 1937

husband were in the acting profession), and also talk about personalities that each had encountered. They continued to see one another and write on much the same lines until the beginning of 1936, when Yeats, who was spending the winter in Majorca, developed congestion of the lungs and was seriously ill for some weeks. Over this period Margot's letters show a progressive diminution of self control and an increase in worry, partly over financial problems, partly over guilt that she was neglecting her young daughter, and partly over technical difficulties she had found in writing her own poems and a couple of plays.

\section{Psychotic episode}

All this suddenly culminated in Margot travelling to Majorca, where very early one morning she arrived unannounced at Yeats's house; she stayed for a few minutes and then disappeared. A few days later she was found in a psychotic state, being looked after in a convent by some nuns; she had been picked up by the sea shore soaked to the skin. The measure of her derangement is shown by an extract from the essay "Almost I tasted Ecstasy":

"It was a physical bliss as though I were dissolved to joy but it worried me because I couldn't explain to my friend about it, and my 
mind went on thinking and worrying. I played with the dog as I had used to do and suddenly it said: 'Run, run for your life,' it did not speak with a voice but I heard it in my mind, I thought it meant the bliss was dangerous and I must run to shake it off. I hurried to my friend's home and when at the door asked if I might take the dog for a run as it was very important. She stared at me. We ran and the dog said 'What shall I be in my next life? Do something now which I cannot do and that will decide.' I jumped on the back of a van horse. The dog, arching its neck proudly, said 'I shall be a horse.' I jumped down and we ran away."

The Yeatses paid for her to be sent back to Britain in the charge of a nurse and a few days after she arrived home her sanity seems to have completely recovered. Indeed, she des-

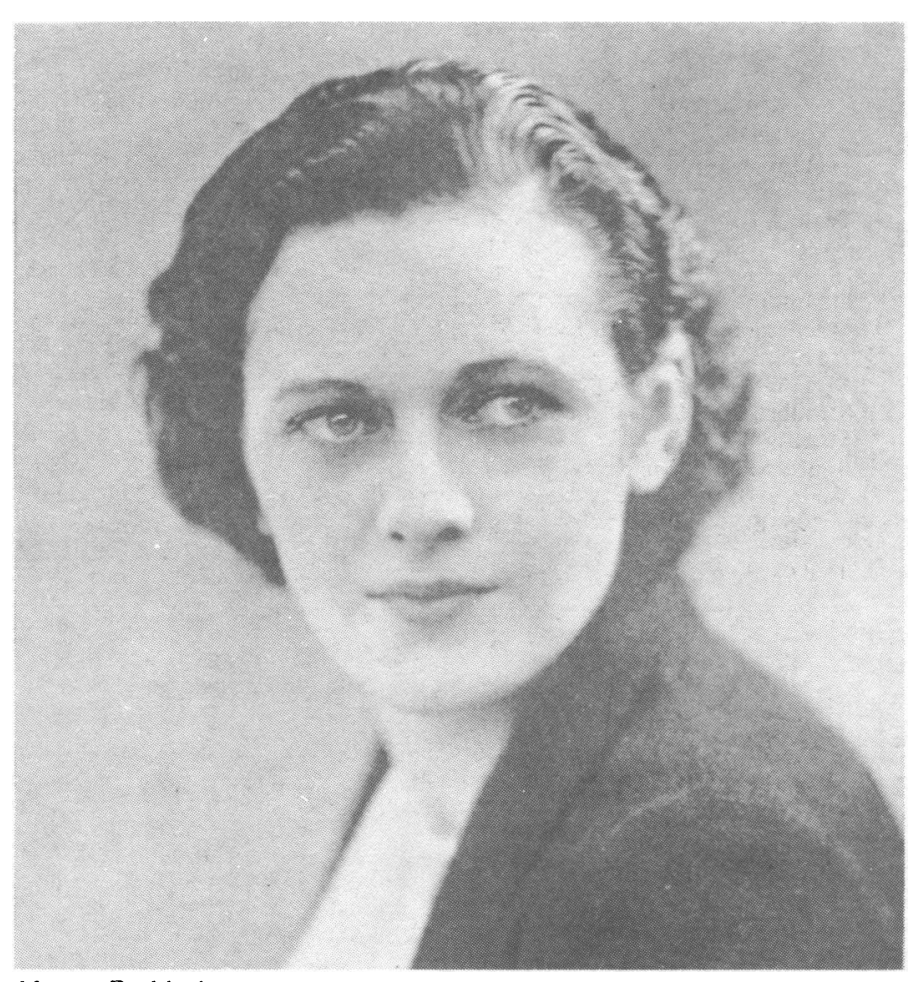

Margot Ruddock.

cribed the whole episode in a book called The Lemon Tree, which also contained some of her poems and an introduction by Yeats. ${ }^{21}$ But after this it seems that the Yeatses carefully avoided her, although in 1937 she did take part in three of the four BBC broadcasts of Yeats's poems for which Yeats spoke the commentary. Before the end of 1937, however, Margot's mental condition relapsed; she was admitted to an asylum at Epsom, where she stayed in the same state until her death in 1951 at the age of 44 .

I believe that this episode is likely to have been connected with the Steinach operation. Most reports mention that immediately after the operation there was an increase in sexual interest, and that this persisted for about a year. Yeats had been a passionate man in his youth, and the operation reawoke his feelings after a period of lack of interest, caused, I suspect, as much by his hypertension and recurrent heart failure as by being middle aged. But that all this did happen is confirmed by a letter that Yeats wrote in 1937 in which he declined a pressing invitation to lecture in India. "Please tell him of the operation I went through in London," he says, "and say that though it revived my creative power it revived also sexual desire; and that in all likelihood will last me until I die. I believe that if I repressed this for any long period I would break down under the strain as did the great Ruskin." "2

I do not believe that we should laugh or sneer at Yeats over this. Attempts to restore youth or sexual potency must be almost as old as man himself. Although the Steinach operation was made out of date by the subsequent isolation of purified sex hormones, this did not stop people with the money from trying out other fringe medical practices. We know that people as diverse as Pope Pius XII, Konrad Adenauer, Somerset Maugham, and the Duke and Duchess of Windsor all had courses of Niehans's cellular treatment in Switzerland-and interestingly enough in his early days as a surgeon Nichans did perform Steinach operations. On the other side of the Iron Curtain, injections of procaine, or H3, have been very popular, and the Communist gerontocracy are said to have travelled to Dr Anna Aslan's clinic in Romania for treatment.

Would things today, almost 50 years later, have been any better? Yeats would, I suppose, have been advised against smoking cigarettes and his heart failure would have been treated vigorously. Almost certainly, he would not have escaped being given beta blockers-and what would their side effects have done to him? Remember what a professor at St Thomas's has said about taking beta blockers as a volunteer in an experiment-and remember that this description is by a healthy man:

This drug induces quite unpleasant side effects. To start with, I have been continuously lethargic. It has been difficult to summon up enough drive to get things done in normal fashion. Early bed times have been needed, but sleep has been disturbed by some bad dreams and I have twice awakened suddenly during the night totally disoriented and confused about my whereabouts. During the day, physical weariness and aching thigh muscles have accompanied any exertion, not only on the bicycle ergometer used to test the drug's action, but also when gardening or going upstairs. To make an absolute judgment on the real value for the individual patient is difficult, though, of course, as doctors we may not have to make the decision in practice because patients who suffer bad side effects will probably stop taking their tablets. I may well be among them. ${ }^{23}$

To conclude, medical treatment, I believe, may sometimes help the patient's physical condition at the expense of his spiritual life. What would have happened to Virginia Woolf if she had been given lithium or one of the benzodiazepines for her mania or depression? Or take another example from music. In 1910 Gustav Mahler died from subacute bacterial endocarditis; he worked until the end of his life, sketching out the marvellous 10th symphony. Over 60 years later Benjamin Britten developed the same illness and, though the infection was cured by modern antibiotics, it damaged his heart valve so much that he was advised to have it replaced as a matter of urgency. Sensibly, I believe, he chose to finish his masterpiece Death in Venice before he had the operation. We know, of course, that the operation was complicated by a hemiplegia and that for the remaining three years of his life Britten's health was poor and his musical output was small compared with that before the operation.

So we should perhaps be thankful that Yeats escaped modern medicine. Yeats himself commented on this: "I have a slip-shod Spanish doctor who says 'I am not a mechanical doctor, I work by faith.' He said to me the other day 'I am a bad doctor but I have done you more good than the good doctors did.' . . . Heaven knows if he meant to say that, but the last part is true." ${ }_{24}$ He lived, albeit precariously, for 12 years with his illnesses and gave us those marvellous poems of his final period. Without the Steinach operation and without Margot Ruddock would we ever have had this?

That crazed girl improvising her music, Her poetry, dancing upon the shore, Her soul in division from itself Climbing, falling she knew not where, Hiding amid the cargo of a steamship, Her knee-cap broken, that girl I declare A beautiful lofty thing. ...

For their help in preparing this paper I thank Mr A W Badenoch, Dr Eoin O'Brien, Mr Barry O'Donnell, Dr A C B Hooper, Mr John Kelly, Professor Roger McHugh, Dr Cornelius Medvei, and Professor Jon Stallworthy. Mr Brian McKenna and Mr Richard Mooney, of the National Library, Dublin, kindly arranged for me to consult an 
extensive number of documents relating to W B Yeats. Extracts from Yeats's poems and Professor McHugh's Ah, Sweet Dancer are reproduced by kind permission of Macmillan and Michael Yeats.

\section{Addendum}

Since I wrote this article my friend Professor J B Lyons of Dublin has told me that Yeats's Steinach operation was mentioned in some letters written by Gogarty to Horace Reynolds, a lifetime friend and a Boston man of letters, which are now in the Houghton Library at Harvard. In October 1934 Gogarty says that Yeats "has undergone Steinach's operation and is now trapped and enmeshed in sex. When I parodied his poem into

I heard the old, old men say

Everything's phallic

little did I think he would become so obsessed before the end. He cannot explode it by pornography (as Joyce) or jocularity as I try to do."

On 9 March 1955 Gogarty mentions that Yeats "submitted to that humbug, Steinach . . . he never consulted me . . . Ethel Mannin told me that she 'did my best for him' after the operation; but of course without effect!"

\section{References}

${ }^{1}$ Yeats WB, ed. Oxford book of modern verse. Oxford: Oxford University Press, 1936.
${ }^{2}$ Medvei C. A history of endocrinology. Lancaster: MTP Press, 1982 : 336-7.

${ }^{3}$ Anonymous. Borrowed youth. MD Sept $1981: 204-8$

* Schutte H, Herman JR. Eugen Steinach, 1861-1944. Investigative Urology $1975 ; \mathbf{1 2}: 330-1$

5 Steinach E, Lobel J. Sex and life. London: Faber and Faber, 1941.

"Yeats WB. In: Wade A, ed. The letters of $W B$ Yeats. London: Hart-Davis, $1954: 796$.

${ }^{7}$ Hone J. W B Yeats: man and artist. London: Macmillan, 1942.

${ }^{8}$ Stallworthy J. Between the lines. Oxford: Oxford University Press, 1963.

9 Stallworthy J. Vision and revision in Yeats's last poems. Oxford: Oxford University Press, 1969.

${ }^{10}$ Macliamoir M, Boland E. W B Yeats and his world. London: Thames and Hudson, 1971:109.

11 Tuohy F. W B Yeats. London: Macmillan, 1980.

12 Haire N. Rejuvenation: London: Allen and Unwin, 1934.

${ }^{13}$ Yeats WB. In: Wade A, ed. The letters of W B Yeats. London: Hart-Davis, 1954:845.

14 Yeats WB. In: Wade A, ed. The letters of W B Yeats. London: Hart-Davis, $1954: 814$

15 Yeats WB. Manuscript letter in National Library, Dublin.

${ }^{16}$ Yeats WB. In: Wade A, ed. The letters of W B Yeats. London: Hart-Davis, 1954:822.

17 Yeats WB. In: Wade A, ed. The letters of W B Yeats. London: Hart-Davis, 1954:823.

18 Yeats WB. In: Wade A, ed. The letters of W B Yeats. London: Hart-Davis, $1954: 836$

18a Strong LAG. Draft review of ref (7). Manuscript in National Library, Dublin.

${ }^{19}$ Macliamoir M, Boland E. W B Yeats and his world. London: Thames and Hudson, 1971:127.

20 McHugh R. Ah, sweet dancer. London: Macmillan, 1970.

21 Ruddock M. The lemon tree. London: Dent, 1937.

22. McHugh R. Ah, sweet dancer. London: Macmillan, 1970:117.

23 Smith SE. Personal view. Br Med f 1982;284:818.

24 Yeats WB. In: Wade A, ed. The letters of W $B$ Yeats. London: Hart-Davis, $1954: 853-6$.

\section{The origin of "Awakenings"}

\section{OLIVER SACKS}

I have been asked by the editor to write about the genesis of Awakenings. This necessitates a sort of medical autobiographybut a sort that I hope may have some real interest and not be merely egocentric or confessional.

I had been fairly orthodox in my neurological training and in my early days as a neurologist had not felt impelled to step out of the formats of established medical formulation and writing. Thus my first book, Migraine, originally written in 1967, was well within the established medical "canon."

When, early in 1969, I embarked on the work which was later to become Awakenings I conceived it in quite limited, and narrowly "scientific," terms-as a 90 day double blind trial of levodopa in a large group of patients who had become institutionalised after having encephalitis. Consciously, at least, I thought of it as little more than this, but there must have been, unconsciously, complex depths below-depths of uncertainty, depths of concern-which caused me, as I did, to hesitate for two years (Cotzias's famous paper had been published in February 1967'). These were not "ordinary" patients with Parkinson's disease: they had far more complex pathophysiological syndromes, and their situations were more complex, indeed without precedent-for they had been "institutionalised," and "out of the world," for decades-sometimes since the time of the

\section{Albert Einstein College of Medicine, New York}

OLIVER SACKS, MD, professor of neurology

Correspondence to: Dr Oliver Sacks, 119 Horton Street, City Island, NY 10464. great epidemic. Thus, even before I started, I was faced by scientific and human complexities, complexities and perplexities of a sort which had not arisen in previous trials of levodopa, or, indeed, of any treatment in the past. Thus there was an element of the extraordinary, the unprecedented, the unpredictable. I was setting out, with my patients, on an uncharted sea. . . .

And, indeed, it became obvious within a month or less that the original format would have to be abandoned. The effects of levodopa in these patients was decisive-spectacular; while, as I could infer from the precise $50 \%$ failure rate, there was no significant placebo effect whatever. I could no longer, in good conscience, continue the placebo but had to try levodopa in every patient; and I could no longer think of giving it for 90 days and then stopping-this would have been like stopping the very air that they breathed. Thus what was originally conceived as a limited 90 day experiment was transformed instead into an historical experience: a story, in effect, of life for these patients as it had been before levodopa, and as it was changed, and as it was to become, after starting treatment with levodopa.

Thus I was impelled, willy nilly, to a presentation of case histories or biographies for no "orthodox" presentation, in terms of numbers, series, grading of effects, etc, could have conveyed the historical reality of the experience. In August 1969, then, I wrote the first nine case histories, or "stories, "of Awakenings.

The same impulse, the same sense that one had to convey stories and phenomena-the drama of stories, the delight of phenomena-led me to write a number of "letters to the editor," which I despatched to the Lancet and the BMF early the next year. I enjoyed writing these letters, and, as far as I could gather, readers of these journals enjoyed reading them too. There was 